\title{
Stability of Styrax benzoin extract and fraction with the addition of glycerol and tween 80
}

\author{
Dedi P Simatupang ${ }^{1, *}$, Nora Susanti ${ }^{2}$ and Jamalum Purba ${ }^{2}$ \\ ${ }^{1}$ Chemistry Study Program, Faculty of Mathematics and Natural Sciences, Universitas Negeri Medan, \\ Indonesia \\ ${ }^{2}$ Department of Chemistry, Faculty of Mathematics and Natural Science, University Negeri Medan, \\ Medan 20221, Indonesia \\ *Corresponding author: DPS, dedipebriwantosimatupang@gmail.com
}

DOI: 10.24114/jpkim.v13i2.26986

Article history:

Received: 19 June 2021

Revised: 15 July 2021

Accepted: 16 July 2021

\begin{abstract}
This research to decide the consequences of expanding the steadiness of the concentrate and part of incense with the expansion of glycerol and tween 80 by contrasting the reference tests of frankincense separates available. The technique utilized in this examination depends on the expansion of glycerol and tween 80 , just as directing boundaries of consistency, organoleptic, $\mathrm{pH}$ and investigation of substance content of concentrates and parts with GC-MS instruments. The outcomes got in this investigation demonstrate the actual properties of the concentrate and part of the incense sap as a thick fluid, earthy red and has an unmistakable fragrant smell. The consistency got from the thickness test was $277.68 \mathrm{Cp}$. In the meantime, the thickness estimation consequences of the reference test acquired a consistency worth of $326.54 \mathrm{CP}$. What's more, has a pH scope of 4.05.5. The fundamental synthetic parts of the extraction results and the isoprophyl part of styrax benzoin and the reference part of the reference styrax benzoin remove dependent on the consequences of the investigation discovered 6 mixtures that share practically speaking, in particular Benzoic corrosive, Vanillin, trans-Cinnamic corrosive, (Z) - Cinnamyl benzoate, 2-Propenoic corrosive , 3-phenyl-, phenylmethyl ester, (E) - and Cinnamyl cinnamate.
\end{abstract}

Keywords: Styrax benzoin, Glycerol, Extract stability, Tween 80, Fractionation

\section{Introduction}

Styrax benzoin comes from dry sap (exudate), which is delivered by chiseling the storage compartment of an incense tree (Styrax spp., Styracaceae clan; particularly S. benzoin Dryand. Also, S. paralelloneurus Perkins). Dry gum is as white or whitish chips, which are submerged in a reasonable dim or ruddy earthy colored mass, hard however brittle, and scents great. Incense sap has numerous advantages for people and is likewise a vital fare ware. Incense sap contains $\pm 36.5 \%$ cinnamic corrosive as a crude material for the 
corrective and drug enterprises. Incense trees can be utilized for reforestation, land recovery and cook bulkhead trees (Apriyanti, 2017).

Today, the utilization of benzoin gum has been extended not exclusively to be utilized as scents and incense on account of its fixative impacts yet additionally utilized as a cell reinforcement in the beautifying agents industry and flavor enhancers in the food business. The restorative and pharmacological impacts of sanitizing (against bacterial) and expectorants in benzoin gum are likewise utilized in the drug business. Truth be told, benzoin gum in the Asian locale has been utilized in injury mending, erythema and hack (Hidayat et al. 2019).

In the fragrance business, its fundamental use is as a "fix dynamic", what capacities to hold the smell in the scent to make it last more and as a "fix specialist", what capacities to unite two or a few kinds of scent from various fixings to improve fragrance. Through the esterification interaction, cinnamic corrosive is utilized to shape esters, for example, methyl and ethyl just as different subsidiaries which are broadly utilized for the requirements of agrarian drugs (Jayusman, 2014).

The steadiness of an arrangement is something that should be thought of. This is significant looking at that as a planning is normally delivered in enormous amounts and consumes most of the day to arrive at the buyer. Hence, these arrangements additionally should be tried for soundness as per foreordained strategies. Stable concentrate arrangements are arrangements that are still inside adequate cutoff points during the capacity and use period (Mardikasari et al. 2017).

Subsequently, this examination needs to foster the soundness of the concentrate and part of incense with the expansion of glycerol and tween 80 so the concentrate and part of incense sap can be formed into arrangements in the aroma business. Where the solidness of the concentrate and part of incense with the expansion of glycerol and tween 80 will be seen dependent on organoleptic boundaries, thickness, $\mathrm{pH}$ and GC-MS examination and contrast and reference frankincense remove tests.

\section{Methods}

2.1 Materials, sample and population

The research was conducted at the Research Laboratory of the Department of Chemistry, State University of Medan. The tools used in this research are analytical balance, a set of glassware, maceration bottles, indicator $\mathrm{pH}$ universal, aluminum foil, rotary evaporator, Ostwald Viscosity and GC-MS. The materials used in this study were 80 mesh of $500 \mathrm{~g}$ styrax benzoin powder samples from the Parsoburan area, Ethanol (pa), glycerol (p.a), isoprophyl alcohol (p.a) and tween 80.

\subsection{Extraction}

An aggregate of $500 \mathrm{~g}$ of incense gum powder was removed by maceration utilizing ethanol p.a dissolvable until all examples were maseration in a glass container for $3 \times 24$ hours while mixing every so often. Following 3 days, the macerated tests were isolated by sifting. From that point forward, all the filtrate acquired was concentrated utilizing a revolving evaporator until the example turned out to be thick. Part of the way thick concentrates were exposed to phytochemical tests to decide the class of mixtures contained in the concentrate, and a large portion of them were fractionated. After the 
fractionation was done, phytochemical screening tests were completed to decide the optional metabolite compounds from fractionation sap (Khasanah et al. 2020).

\subsection{Fractionation}

The ethanol extricate was then fractionated fluid with an isolating channel utilizing isoprophyl liquor as a dissolvable. The ethanol extricate is placed in an isolating pipe in which isoprophyl liquor dissolvable is added with a proportion of $1: 1$ then, at that point shaken gradually while incidentally opening the top of the isolating channel to eliminate the current gas, then, at that point the fractionation results are vanished again with a turning evaporator (Khasanah et al. 2020).

\subsection{Addition of glycerol and tween 80}

An example of $5 \mathrm{~mL}$ of each portion was added to a glass recepticle containing $5 \mathrm{ml}$ of glycerol in a half $\mathrm{w} / \mathrm{v}$ equation ( $5 \mathrm{~mL}$ of glycerol and $5 \mathrm{~mL}$ of ethanol) and $2 \mathrm{~mL}$ Tween 80 . A glass measuring utencil containing an answer of the portion with glycerol and tween 80 is blended utilizing an attractive stirrer at a temperature of $25^{\circ} \mathrm{C}$. After balance is reached, the soaked arrangement is separated (Ghorab et al. 2015).

2.5 Viscosity test

Estimation of consistency is by utilizing the Ostwald viscosimeter. The assurance is finished by estimating the time needed for the cosolvent answer for stream in the slim cylinder from $a$ to $b$. The arrangement of Kosolven was placed into the viscometer. Kosolven arrangement is sucked by siphon until it is over the imprint a. The liquid is permitted to stream downwards and the time taken from $a$ to $b$ is recorded utilizing a stopwatch (Apriani et al. 2013).

\section{$2.6 \mathrm{pH}$ test}

The $\mathrm{pH}$ test is done utilizing a $\mathrm{pH}$ all inclusive, the shading that seems is contrasted with the standard tone in the proper $\mathrm{pH}$ range (Tambunan, 2018).

\subsection{Organoleptic test}

Organoleptic test incorporates perception of lucidity, shading and scent (Mulyani, 2016). Stable concentrates should show a similar clearness, shading and smell qualities after sped up capacity (Megawati et al. 2015).

\subsection{GC-MS analysis}

The ethyl acetic acid derivation division remove examination was done at the Medan Customs Laboratory. The arrangements were broke down by GC-MS utilizing the GCMS $7890 \mathrm{~B}$ framework, with a HP1 segment (30 $\mathrm{m} \times 250 \mu \mathrm{m} \times 0.25 \mu \mathrm{m})$. The underlying temperature of the $\mathrm{GC}$ stove is $90{ }^{\circ} \mathrm{C}$ and customized to $110^{\circ} \mathrm{C}$ with a predetermined speed of $15{ }^{\circ} \mathrm{C} / \mathrm{min}$ and afterward exposed to $240{ }^{\circ} \mathrm{C}$ for 22 minutes under the accompanying working conditions: transporter gas, helium; injector and identifier temperature, $280^{\circ} \mathrm{C}$; volume infused, $1 \mu \mathrm{l}$ (20\% hexane arrangement). The mass range was performed on typical filtering, mass reach 30-450.

\section{Results and Discussion}

3.1 Extraction and fractionation 
The utilization of maceration strategy for the interaction Styrax benzoin extraction, other than dependent on viability, commonsense, protected, conservative, likewise reason to keep away from the breakdown of the dynamic compound of styrax benzoin (Simorangkir, 2017; Susanti et al. 2021). The utilization of ethanol dissolvable in this extraction means to have the option to draw in all in all the mixtures contained in the polar Styrax benzoin. Subsequent to dousing the styrax benzoin powder for $3 \times 24$ hours, the filtrate is sifted. Sifting is done utilizing a Buechner pipe. The subsequent filtrate from the macerated concentrate of the styrax benzoin powder was then thought with a rotating evaporator at a temperature of $75^{\circ} \mathrm{C}$ (Situmeang, 2016). The outcomes from the rotating evaporator acquired a thick concentrate of the incense gum powder with earthy dark tone.

\subsection{Addition of glycerol and tween 80}

Glycerin is utilized as a dissolvable or cosolvent in creams and emulsions. Glycerin is furthermore utilized in watery and nonaqueous gels and furthermore as an added substance in fix applications. In parenteral plans, glycerin is utilized essentially as a dissolvable and cosolvent. In oral arrangements, glycerin is utilized as a dissolvable, improving specialist, antimicrobial additive, and thickness expanding specialist. It is likewise utilized as a plasticizer and in film coatings. Glycerin is utilized as a plasticizer of gelatin in the creation of delicate gelatin containers and gelatin suppositories (Rowe et al. 2009). Aside from that, glycerol is one of the transporter materials for strong and semisolid arrangements what capacities as an additive, cosolvent, emollient, humectant, plasticizer, sugar, and constitution specialist. After the expansion of glycerol to the negligible part of the incense sap, which was utilized as a cosolvent, then, at that point blended for 2 hours and separated utilizing channel paper and the outcome was the expansion of a cosolvent in a thick, earthy red fluid. The primary parts of the substance mixtures of frankincense sap are cinnamic corrosive and benzoate corrosive, the two of which have low water dissolvability. With the goal that it causes the incense sap to be hard to break up in water To build the solvency of a substance in water, it tends to be done severally, including salt arrangement, complex development, expanding temperature, diminishing molecule size or adding surfactants (Augustin \& Brewster, 2007). Aside from the option of glycerol to the concentrate tests and the small amount of the incense gums, tween 80 (Polysorbate 80 ) was additionally added. Giving tween 80 (Polysorbate 80 ) as a solubilizing specialist which has lipophilic properties so it can blend in with oil. The construction of Tween 80 significantly influences the increment in infiltration of the planning (Masruariati, 2014). With the expansion of tween 80 , the concentrate and part of incense sap are steady when blended in with water.

\subsection{Viscosity, $\mathrm{pH}$, organoleptic}

The aftereffects of the consistency estimation got the worth of the thickness of 277.68 $\mathrm{CP}$. While in the reference test consistency estimation results acquired a thickness worth of $326.54 \mathrm{CP}$. The example extricate and isopropyl liquor part have lower consistency than the reference test. Consistency is straightforwardly relative to the bond of the arrangement, the more noteworthy the thickness esteem, the more extended the capacity of the readiness to stick. Expanded contact season of the readiness will be gainful when applied to the skin (Naibaho et al. 2013). The $\mathrm{pH}$ estimation is done with a widespread $\mathrm{pH}$ marker. The $\mathrm{pH}$ pointer is drenched in the example and the shading change is seen which shows the pH level the example has. The $\mathrm{pH}$ estimation in this investigation is planned to decide the idea of the 
example in disturbing the skin. On the off chance that the $\mathrm{pH}$ of the planning is too acidic it will disturb the skin and in the event that it is too basic it can cause textured skin (Pertiwi et al. 2020). According to Gozali (2009) pH esteems that surpass 7 are dreaded to cause skin disturbance. For ordinary skin it has a pH range between $\mathrm{pH}$ 4.5-6.5.

The aftereffects of the pH estimation of the test went from pH 4.5 to 5.5. For reference tests the estimation results are at $\mathrm{pH} 5$-5.5. From the $\mathrm{pH}$ test that has been done on the two examples, it tends to be seen that the two of them are powerless to $\mathrm{pH}$ being near one another. In this organoleptic test, it was done by seeing straightforwardly with the unaided eye the concentrate and ethyl acetic acid derivation portion straightforwardly (Mardikasari et al. 2017). Where the actual type of the concentrate and part of the incense gum powder is as a thick, tanish red fluid and has a particular scent of Cinnamic corrosive which is the sign of the incense. While the reference test readiness has a thick fluid structure that is caramel red and clear and has a marginally more fragrant smell.

\subsection{GC-MS analysis}

The substance segments of the concentrate and part of incense gums were broke down utilizing the Gas Chromatography-Mass Spectrometry (GC-MS) technique. The rule of GC-MS is the detachment of the segments in the combination by gas chromatography and every part can be made a mass range with higher precision. The aftereffect of partition by gas chromatography is created by a chromatogram, while the consequences of the mass spectrometry assessment of each compound are known as the range (Nurhaen et al. 2016). In this exploration, a correlation was made of the reference test of incense gum remove. The consequences of the chromatogram for each example can be found in the Fig 1 and Fig 2 .

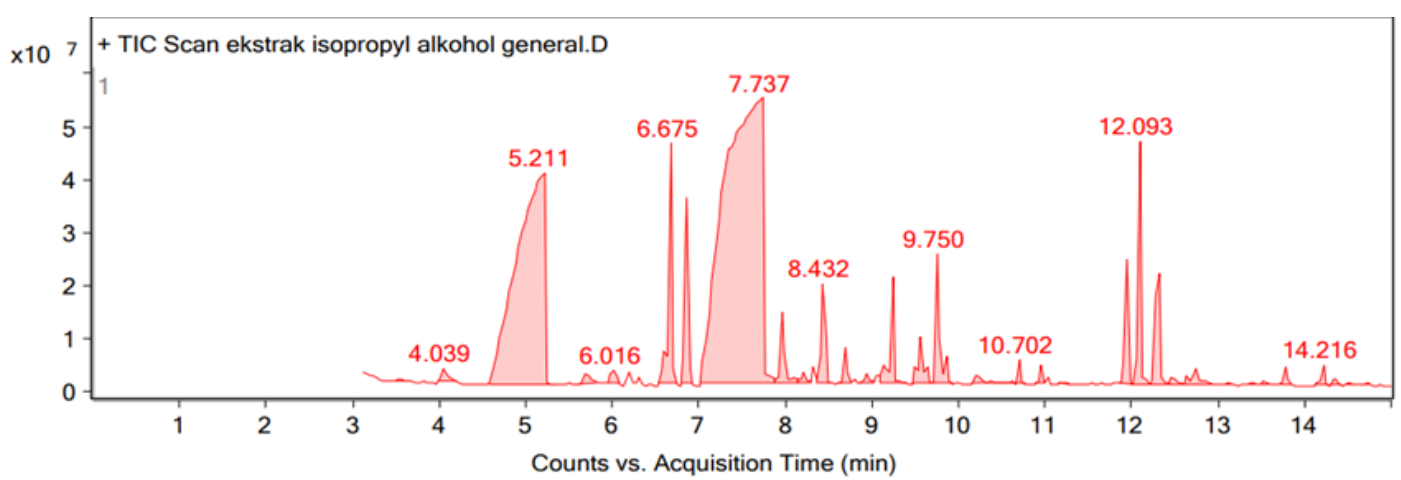

Fig 1. GC-MS chromatogram of isoprophyl alcohol faction of styrax benzoin

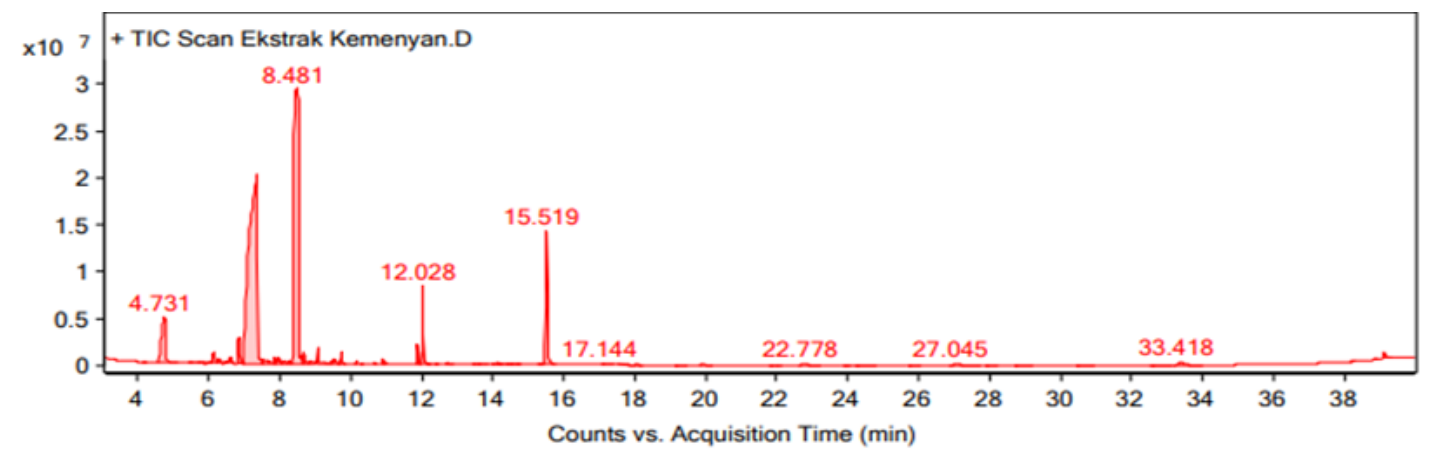

Fig 2. GC-MS Chromatogram of Reference Compound 
From the isopropyl liquor chromatogram and the reference test, there is one pinnacle that is most predominant seen from the percent region individually, to be specific $38.63 \%$, these mixtures are trans cinammic corrosive and 36.08\% which are Diethyl Phthalate compounds.

By taking a gander at the 10 most elevated pinnacle region information for each concentrate, the concentrate of isopropyl liquor part at $\mathrm{rt}$ 7,737 minutes had a percent space of $38.63 \%$ while in the reference test it was 7,336 minutes with a space percent of $40.73 \%$. GCMS investigation for this situation utilizes the GCMS 7890B. In view of the aftereffects of the chromatogram of the isoprophyl liquor portion and the reference remove test, it was tracked down that every one of the primary synthetic segments was displayed in Table 1 and Table 2.

Table 1

GC-MS results of chemical components of ethyl acetate fraction

\begin{tabular}{c|l|l|l}
\hline Peak & $\begin{array}{c}\text { Retention } \\
\text { time }\end{array}$ & \multicolumn{1}{|c}{$\begin{array}{c}\text { \% area } \\
\text { sum }\end{array}$} & \multicolumn{1}{c}{ chemical components } \\
\hline 1 & 5.211 & 20.62 & Benzoic acid \\
\hline 2 & 6.675 & 2.94 & 2-Propenoic acid, 3-phenyl-, methyl ester \\
\hline 3 & 6.858 & 1.91 & Vanilin \\
\hline 4 & 7.737 & 38.63 & trans-Cinnamic acid \\
\hline 5 & 9.238 & 1.49 & (E)-2,6-Dimethoxy-4-(prop-1-en-1-yl)phenol \\
\hline 6 & 9.75 & 2.01 & Benzoic acid, phenylmethyl ester \\
\hline 7 & 11.947 & 1.4 & (Z)-Cinnamyl benzoate \\
\hline 8 & 12.093 & 2.63 & 2-Propenoic acid, 3-phenyl-, phenylmethyl ester, (E)- \\
\hline 9 & 12.313 & 1.96 & cis-13-Octadecenoic acid \\
\hline 10 & 15.754 & 9.79 & Cinnamyl cinnamate \\
\hline
\end{tabular}

Table 2

GC-MS results of reference chemical components

\begin{tabular}{c|l|l|l}
\hline Peak & $\begin{array}{c}\text { Retention } \\
\text { time }\end{array}$ & $\begin{array}{c}\text { \% area } \\
\text { sum }\end{array}$ & \multicolumn{1}{c}{ chemical components } \\
\hline 1 & 4.731 & 5.71 & Benzoic acid \\
\hline 2 & 6.837 & 1.32 & Vanillin \\
\hline 3 & 7.336 & 40.73 & Trans cinnamic acid \\
\hline 4 & 8.481 & 36.08 & Diethyl Phthalate \\
\hline 5 & 8.666 & 0.45 & n-propyl cinnamat \\
\hline 6 & 9.072 & 0.58 & Phthalic acid, ethyl isopropyl ester \\
\hline 7 & 9.737 & 0.37 & Benzyl benzoate \\
\hline 8 & 11.88 & 0.54 & (Z)-cinnamyl benzoate \\
\hline 9 & 12.028 & 1.9 & 2-propenoic acid, 3-phenyl-,phenylmethyl ester,(E)- \\
\hline 10 & 15.519 & 6.76 & Cinnamyl cinnamate \\
\hline
\end{tabular}


Analysis of the ethyl isopropyl alcohol fraction extract resulted in more identified compounds than the reference sample extract. From the similarities between the ethyl acetate fraction extract and the reference sample extract, it can be seen that the process of stability of the extract and fraction of incense gum with the addition of glycerol and tween 80 can be done well.

\section{Conclusion}

The concentrate and part of the incense sap with the expansion of glycerol and tween 80 has great actual strength, where the actual properties of this kind are as an unmistakable caramel red thick fluid and have a particular fragrant smell. The expansion of glycerol and tween 80 can build the strength of the concentrate and part of the incense, which at first appears as balsamate into an unmistakable thick fluid. The pH estimation aftereffects of the concentrate and part of the incense sap went from $\mathrm{pH} 4.5-5.5$. The aftereffects of the consistency estimation got the worth of the thickness of $277.68 \mathrm{CP}$. Though in the reference test consistency estimation results acquired a thickness worth of $326.54 \mathrm{CP}$.

\section{References}

Apriani, D., Gusnedi, G., \& Darvina, Y. (2013). Studi tentang nilai viskositas madu hutan dari beberapa daerah di sumatera barat untuk mengetahui kualitas madu. Pillar of Physics, 2(1), 91-98.

Apriyanti, M. (2018). Getah kemenyan sebagai bahan aditif pada campuran aspal Ac-Wc ditinjau dari sifat fisik bahan aspal dan nilai stabilitas marshall. Jurnal Konstruksia, 9(1), 15-26. DOI:10.24853/jk.9.1.15-26

Augustijns, P., \& Brewster, M. E. (Eds.). (2007). Solvent systems and their selection in pharmaceutics and biopharmaceutics. New York: Springer.

Ghorab, M., Nassar, A., Khafagy, E. S., \& Gad, S. (2015). A pharmaceutical study of various additives on itraconazole as solubilized systems for ocular delivery. World Journal of Pharmaceutical Research, 4(10), 61-89.

Gozali, D., Abdassah, M., Subghan, A. L. A. S., \& Lathiefah, S. A. (2009). Formulasi krim pelembab wajah yang mengandung tabir surya nanopartikel zink oksida salut silikon. Jurnal Farmaka, 7(1), 37-47.

Hidayat, N., Yati, K., Krisanti, E. A., \& Gozan, M. (2019). Extraction and antioxidant activity test of black Sumatran incense. AIP Conference Proceedings, 2193, 030017. DOI:10.1063/1.5139354

Jayusman. (2014). Mengenal pohon kemenyan (Styrax Spp.). Jakarta: IPB Press.

Khasanah, N. W., Karyadi, B., \& Sundaryono, A. (2020). Uji fitokimia dan toksisitas ekstrak umbi Hydnophytum sp. terhadap artemia salina leach. PENDIPA Journal of Science Education, 4(1), 4753. DOI:10.33369/pendipa.4.1.47-53

Mardikasari, S., Nafisah, A., Adjeng, T., Ode, W., Zubaydah, S., \& Juswita, E. (2017). Formulasi dan uji stabilitas lotion dari ekstrak etanol daun jambu biji (Psidium guajava L.) sebagai antioksidan. Jurnal Farmasi, Sains dan Kesehatan, 3(2), 28-32. DOI:10.33772/pharmauho.v3i2.3542

Masruariati, E. (2014). Pengaruh konsentrasi tween 80 sebagai emulglator pada karakteristik krim minyak atsiri daun cengkeh. Jurnal Farmasetis, 3(1), 11-19.

Megawati, M., Roosevelt, A., \& Akhir, L.O. (2019). Formulasi dan uji stabilitas fisik sediaan gel ekstrak kulit buah rambutan (Nephelium lappaceum L.) sebagai obat sariawan menggunakan variasi konsentrasi basis carbopol. Jurnal Farmasi Sandi Karsa, 5(1), 5-10.

Mulyani, N.S. (2016). Pengaruh penambahan tepung maizena terhadap daya terima velva jambu biji. Jurnal Pendidikan Kimia, 8(1), 37-44. DOI:10.24114/jpkim.v8i1.4423 
Naibaho, O. H., Yamlean, P. V. Y., \& Wiyono, W. (2013). Pengaruh basis salep terhadap formulasi sediaan salep ekstrak daun kemangi (Ocimum sanctum L.) pada kulit punggung kelinci yang dibuat infeksi Staphylococcus aureus. Pharmacon, 2(2), 27-33.

Nurhaen, N., Winarsii, D., \& Ridhay, A. (2016). Isolasi dan identifikasi komponen kimia minyak atsiri dari daun, batang dan bunga tumbuhan salembangu (Melissa sp.). Natural Science: Journal of Science and Technology, 5(2), 149-157. DOI:10.22487/25411969.2016.v5.i2.6702

Pertiwi, D., Desnita, R., \& Luliana, S. (2020). Pengaruh pH terhadap stabilitas alpha arbutin dalam gel niosom effect of $\mathrm{pH}$ on alpha arbutin stability in niosomal gel. Jurnal Majalah Farmaseutik, 16(1), 91-100. DOI:10.22146/farmaseutik.v16i1.49446

Rowe, R.C., Sheskey, P., \& Quinn, M. (2009). Handbook of pharmaceutical excipients. London. Libros Digitales- Pharmaceutical Press

Simorangkir, M., Surbakti, R. Barus, T. \& Simanjuntak, P. (2017). Secondary metabolities phytochemical analysis of leaves and fruit extract Solanum blumei Nees ex Blume local. Jurnal Pendidikan Kimia, 9(1), 244-248. DOI:10.24114/jpkim.vgi1.6186

Situmeang, B., Nuraeni, W. Ibrahim, A.M. Silaban, S. (2016). Analysis of secondary metabolite compounds from leaves extract kesambi (Schleichera oleosa) and antioxidant activity test. Jurnal Pendidikan Kimia, 8(3), 164-168. DOI:10.24114/jpkim.v8i3.4479

Susanti, N., Purba, J., \& Simatupang, D. P. (2021). Increased stability of styrax benzoin extract and fraction with the addition of cosolvents. Journal of Physics: Conference Series, 1819012049. DOI:10.1088/1742-6596/1819/1/012049

Tambunan, S., \& Sulaiman, T. N. S. (2018). Formulasi gel minyak atsiri sereh dengan basis HPMC dan Karbopol. Majalah Farmaseutik, 14(2), 87-95. 